our opinions if there had been need to do so. But the main facts remain unaltered, and no glowing description of the well-kept grounds and rapid drains of Londesborough Lodge will get rid of the fact that three persons who had stayed there were seized with typhoid fever, and that one - viz., Mr. Sykes's groom-could have taken the infection nowhere else. Mr. Dale says there has not been a case of typhoid fever for twenty years in any of the twenty-four villas surrounding Londesborough Lodge. But he has perhaps forgotten that two ladies died of it a few years ago in Grove House, through which the pure and rapid sewer of Londesborough Lodge aotually passes, the house itself being close outside the grounds. Upon the question of the death-rate we may have much to say hereafter, but the statement that the death-rate of the inhabitants of New Scarborough is actually less than 6 per 1000 is too much for our belief. It is not necessary to say anything on the medical aspect of the question. Mr. Dale has already given his opinion that diarrhcea might have been caused by the air of Londesborough Lodge, and it is indeed significant that he has attended 900 cases of diarrhœea amongst the visitors in the last ten years. We regret that Mr. Dale should have attempted to connect the case of the groom Blegg with that of the other patients. They had nothing in common except the date of their attacks, and at the time of infection were hundreds of miles apart. The crucial case of Mr. Sykes's butler and that of Lord Chesterfield prove that it is not necessary to look to Sandringham as the source of the illness of H.R.H. the Prince of Wales. 'The groom's illness had the same origin as the West Newton cases, and was clearly referable to the impure water.-ED. I.

\section{REGINA V. WATSON.}

To the Editor of THE LANCET.

Sir,-As I have been made to occupy, through the exceptionally severe and not over-courteous cross-examination at the Old Bailey, a more conspicuous position than I had desired before the public, perhaps you will permit me to give the reasons why I held, and do hold, that the prisoner in the above case was, and is, of unsound mind; and, subsequently, to briefly comment on each head.

1st. There were the evidences of pre-existent melancholia. $2 n d$. The ferocity with which the deed was committed.

3rd. Its utterly senseless character.

4th. The calmness and indifference of the prisoner's manner after the deed was done.

5 th. His justification of suicide, and the expression of his belief that God would forgive the homicide under the circumstances.

1st. As regards the proofs of mental disease prior to the act, they were deposed to by the Rev. Folliott Baugh and his wife as existing a month before the murder; by Mr. $H$. Rogers on the preceding day ; whilst further evidence on this head, not available for the defence owing to the sickness of the deponent, has since been forwarded to the Home Secretary, the statement being that, some months before, he was in communication with the prisoner for the purpose of employing him in his school, but, on an interview, he found his mental condition to be such that he at once broke off the engagement; the evidences of aging and altered aspect deposed to by the secretary of the school a short while after his dismissal. And mark, that to him was no ordinary event : at sixty-seven he found himself suddenly without employment, without any realised money, absolute penury in the not distant prospective, whilst during the nine months he had been thus thrown in upon himself, every attempt to add to his means, or to obtain an engagement, whether literary or scholastic, had entirely failed.

2nd. Passing to my next point, the ferocity of the act, it was argued by the prosecution that it was done in a fit of rage; but, for the credit of our common human nature, I would ask, is it conceivable that mere anger would so trans- form a mild, quiet old gentleman, as he was shown to be, into such a brutal criminal; so that, not content with slaying his victim, he should go on battering her head and body long after passion alone would have been exhausted. It is, I contend, explicable only as the act of a homicidal melancholic, not otherwise.

3rd. The senseless character of the deed. If done consciously and by premeditation, as the verdict would suppose, I would ask, where could be the gain? Here, again, I argue that the act itself, done without reasonable motive, could only be the product of reason overthrown.

4th. The indifference, \&c. Here I would submit-can a parallel be produced from criminal records in any place (Broadmoor excepted), for the remarkable calmness (selfpossession Mr. Gibson, of Newgate, phrases it) Mr. Watson maintains whenever the act is referred to, such as to lead his old friend, the Rev. J. Wallis, to state "that he seemed perfectly void of shame and remorse; nay, asserting that he was an injured person by being put in prison"?

5th. His justification of suicide, \&c. I may here be met by the remark that he is probably an unbeliever in the Christianity he professed. To this I make reply that there is not a tittle of evidence to show that such is the case. Until the act was done, a regular attendant at church, a constant communicant, his whole moral nature must have become utterly changed and corrupt ere such a consummation could be arrived at, standing out, as it does, in direct antagonism to his previous life, as portrayed by one who knew him well and gives his opinion of his old friend in this day's Times.

I pass over his subsequent blundering attempts to hide the act, as similar things have been done by others whose insanity has not been questioned. And as I have occupied much of your space, I subscribe myself,

Dean-street, Soho, January 15th, 1872. Yours obediently,

\section{A NEW MIDWIFERY FORCEPS.}

To the Editor of THE LANCET.

SIR,-As I find that no comment has been made regarding the "new midwifery forceps" described by Dr. Barclay in your issue of the 6th instant, perhaps you will allow me to state that I have for nearly four years used a forceps similar in every essential particular to that described by Dr. Barclay, which I had made after the pattern of one in the possession of Mr. C. E. Garman, of Bow.

The only points of difference between the forceps I have and Dr. Barclay's are, that in his the female blade is the under one, in mine it is the upper ; in mine the cross stops do not move, and in mine the handle is five inches in length, that is, one inch longer than in Dr. Barclay's ; the measurements in every other particular being identical with those given by him, and the handles being similar.

I can fully endorse Dr. Barclay's opinion regarding their facility of application and efficiency, as I can, from considerable experience, say they are admirably adapted for any case in which the forceps is of use.

I write this, not with the intention of depriving Dr. Barclay of the credit due to him for having devised a forceps new to himself, but to let the profession know that such a forceps has been in use for many years.

$$
\text { I am, Sir, yours faithfully, }
$$
MarK Long, M.D.

Richmond-road, Dalston, E., Jan. 13th, 1872.

\section{HOLE-AND-CORNER SURGERY AT OXFORD.}

To the Editor of THE LANCET.

SiR,-I think the bulk of the profession at Oxford have a grievance which you may help us to remove. We have a large infirmary, with a staff of three physicians and three surgeons. The other medical men in the place are constantly sending patients there who require operative interference in their cases. In most large towns where this is the case the profession, as a matter of courtesy, are admitted to see important operations-as a large infirmary is generally considered as to some extent public property,and lessons to be learned at such an institution are not grudged to the profession at large. Here this is, as far as 